\title{
Cognitive and personality test as a predictor of religious education achievement among students of religious program of Islamic schools in Indonesia
}

\author{
Abdul Muhid1, UIN Sunan Ampel, Indonesia, muhid@uinsby.ac.id ORCID: 0000-0002-6082-3477 \\ Ali Ridho, UIN Maulana Malik Ibrahim, Indonesia, aliridho@uin-malang.ac.id ORCID: 0000-0002-6818-0998 \\ Ahmad Yusuf, UIN Sunan Ampel, Indonesia, ahmadyusuf@uinsby.ac.id ORCID: 0000-0002-7258-7600 \\ Mohammad Kurjum, UIN Sunan Ampel, Indonesia, kurjum@uinsby.ac.id ORCID: 0000-0002-6288-6236 \\ Muhammad Thohir, UIN Sunan Ampel, Indonesia, muhammadthohir@uinsby.ac.id ORCID: 0000-0002-5323-384X \\ Suryani, UIN Sunan Ampel, Indonesia, suryani@uinsby.ac.id ORCID: 0000-0001-9106-1631 \\ Ahmad Hanif Asyhar, UIN Sunan Ampel, Indonesia, hanif@uinsby.ac.id ORCID: 0000-0001-6730-9166
}

\begin{abstract}
Student admission aims at selecting students who can adapt to the school environment and predict students' academic success. The best student admission system is needed to determine the success of religious education in schools that have a religion-based. This paper presents the results of correlation between predictive test study, cognitive and personality tests toward the students' Islamic achievement in Islamic Subject. This research used a quantitative approach and a survey using three measuring instruments; a learning achievement test, cognitive test, and Big Five Personality test. The subjects of this study were 1396 students from 10 Islamic Senior High Schools conducting religious major program in Indonesia. The results of this study indicate that cognitive tests and personality types are significant predictors of religious education achievement. Specifically, verbal tests and reasoning have been significant predictors of religious education achievement as well. Furthermore, from five dimensions of Big Five Personality, the strongest type of personality, openness to experience and conscientiousness are vigorous predictors of the religious education achievement. Agreeableness, extraversion, and emotional stability, however, do not have a significant influence on religious education achievement. Further research can reach the entire national admission system of state Islamic senior high schools in Indonesia namely Islamic senior high schools Insan Cendekia, which is also a state boarding school in Indonesia.
\end{abstract}

Keywords: Cognitive test, big five personality, verbal, reasoning, academic achievement

Received: $13.04 .2020 \quad$ Accepted: $18.06 .2020 \quad$ Published: 15.09 .2020

\section{INTRODUCTION}

One of the Islamic school education systems in Indonesia is the Islamic senior high school, which has a Religious major and/or special program schools (MAPK). MAPK have an education system that specifically teaches students religious education material (Rohmah \& Arifin, 2017). MAPK is boarding schools, which requires students and teachers to stay in the dormitory. The purpose of the boarding education model is that the students are expected to have good manners, discipline, honesty, responsibility, independence and social and environmental care (Arifah et al., 2019; Hastuti \& Jumidah, 2017; Susiyani, 2017).

However, not every student accepted in MAPK can adapt to the boarding school system. Students who cannot adapt well usually ask to go home rather than stay in the boarding school. The common problem for MAPK students is the tightness of educational activities which makes students less focused on learning, less discipline, and overrated Arabic language abilities (Zulfa \& Pardjono, 2013). As a result, students cannot optimally develop their academic achievement (Zulfa \& Pardjono, 2013). Thought, these students were accepted through strict national admission, in some cases, there have not been much empirical data found about the predictive validity of the national admission test for MAPK students in Indonesia.

${ }^{1}$ Corresponding author: Abdul Muhid; Psychology Department, UIN Sunan Ampel Surabaya, Indonesia, Email: $\underline{\text { muhid@uinsby.ac.id }}$ 
Previous research on MAPK in Indonesia is still limited to; institutional issues (Suwendi, 2017); curriculum development (Rohmah \& Arifin, 2017); student religious activities (Azani, 2019; Muslim, 2017; Nur, 2019; Salman, 2016; Surur, 2018); quality management (Rosanti et al., 2018; Warsah \& Nuzuar, 2018). There are limited, if any, research about the admission tests as predictive validity to select MAPK students. Meanwhile, research in the context of State senior high schools (SMA) showed that the Scholastic Talent Test has a significant predictive level of validity to the learning achievements of senior high school students (Krisna, 2019). Permatasari (2016) stated that cognitive and non-cognitive tests are predictors of academic achievement. Similarly, Khafidin (2014) found that religious education subject tests have high validity and reliability to measure student learning achievement. In addition, dealing with the predictive test of personality tests, Ghazi, Shahzada, \& Ullah (2013) revealed that the Big Five personality test can predict academic achievement in mathematics and Islamic education subjects.

For this reason, it is important to measure the predictive tests of cognitive and personality types in the admission of MAPK students in Indonesia since the predictive tests correlate with academic achievement. Due to the importance of cognitive and non-cognitive abilities as a factor of success and academic achievement of students (Khine, 2016), the admission test must include the predictive test of cognitive and personality. The selection process that refers to the psychological test has a significant correlation with students' academic success (Demasi, 2013). According to Urlings-Strop, Stegers-Jager, Stijnen, \& Themmen (2013), it is needed academic and non-academic tests in the selection process of new students with high predictive level. Similarly, Sulphey, Alkahtani, \& Syed (2018) assumed that the scores of new student selection are significantly correlated to academic achievement. In the same way, Noftle \& Robins (2007); Lee, Choi, Kim, \& Choi (2009); Ranasinghe, Ellawela, \& Gunatilake (2012); Hewgley, (2013); Lipnevich, MacCann, \& Roberts (2012); Muñoz, Barraza, Pérez, \& Ortiz (2015); MacKenzie, Dowell, Ayansina, \& Cleland, (2017) showed that the admission tests with cognitive and personality test can predict academic performance.

This research aims to analyze the predictive test of cognitive and personality in selecting MAPK students who can adapt to the school environment and predict students' academic success. This paper describes the results based on an empirical study of the predictive tests of cognitive and personality on the MAPK students' achievement in Indonesia. The cognitive tests consist of verbal and reasoning tests and Big Five personality (openness to experience, conscientiousness, extraversion, agreeableness, and emotional stability) both simultaneously and partially on the achievement of MAPK students; Islamic Studies and Arabic subjects. The finding of this research is expected to be a reference for policymakers to make MAPK students national admission system.

\section{METHODS}

This research was conducted by quantitative approach with a correlational causality design. The survey method was used to collect data from cognitive and personality tests during student admission and students' achievement tests of religious education during their study.

\section{Participant}

The research used a quota sampling technique, quota sampling is a method of non-probability sampling when the samples are selected based on the probability proportionate to the distribution of a variable in the population (Muhid, 2012; Rukmana, 2014). The participants of this research were 1396 students. The participants were selected by a quota sampling technique from 10 Islamic senior high schools with a religious major around Indonesia. Table 1 shows the distribution of the participant.

\section{Instrument}

This study used 3 research instruments; namely (1) learning achievement test; (2) cognitive tests (verbal and reasoning tests); and (3) Big Five Personality tests. Research instruments were developed by an expert-team composing national questions from the assessment center of the 
Directorate of Islamic schools at the Indonesian Ministry of Religion (MORA). The learning achievement test was used to measure the academic achievement of religious education; Islamic Studies and Arabic. Cognitive tests, were administered in 2 sub-tests; verbal tests and reasoning tests. The Big Five personality test was developed based on 5 dimensions: (1) openness to experience; (2) conscientiousness; (3) extraversion; (4) agreeableness; and (5) emotional stability. by using the 3 instruments above, it is expected to be able to test the predictive validity of the admission tests used for the admission of state Islamic senior high school students in Indonesia.

Table 1. Distribution of respondents

\begin{tabular}{lrr}
\hline \multicolumn{1}{c}{ Demography } & Frequency & Percentage \\
\hline Gender & & \\
Male & 662 & $40.89 \%$ \\
Female & 957 & $59.11 \%$ \\
Total & $\mathbf{1 6 1 9}$ & $\mathbf{1 0 0 \%}$ \\
Name of Educational Institution & & \\
MAN 1 Jember & 156 & $9.64 \%$ \\
MAN 1 Surakarta & 153 & $9.45 \%$ \\
MAN 1 Yogyakarta & 52 & $3.21 \%$ \\
MAN 2 Kota Padang Panjang & 487 & $30.08 \%$ \\
MAN 2 Mataram & 119 & $7.35 \%$ \\
MAN 2 Samarinda & 117 & $7.23 \%$ \\
MAN 3 Kota Makassar & 125 & $7.72 \%$ \\
MAN 4 Banjar & 223 & $13.77 \%$ \\
MAN 4 Jombang & 95 & $5.87 \%$ \\
MAN Darussalam Ciamis & 92 & $5.68 \%$ \\
Total & $\mathbf{1 6 1 9}$ & $\mathbf{1 0 0 \%}$ \\
\hline
\end{tabular}

\section{Data analysis}

Multiple linear regression was used to analyze the data. The stepwise technique was used to analyze the effect of each two cognitive sub-tests and the five dimensions of Big Five personality on the students' achievement of religious education. The data analysis entirely uses IBM SPSS Version 25. The multiple linier regression was conducted to analyze the predictive test of cognitive and personality as predictors of MAPK students' religious education achievement.

\section{RESULTS}

The result of the statistical analysis in Table 2 shows that there is a significant simultaneous correlation between cognitive tests (verbal and reasoning) with the religious education achievements of Islamic school students ( $\mathrm{F}=69.154$; $\mathrm{P}=.000)$. Thus, Verbal tests and empirical reasoning can be used as significant predictors of the educational achievement of Islamic school students. 
Table 2. Multiple regression analysis of cognitive test on religious education achievement

\begin{tabular}{cc}
\hline Statistic & Value \\
\hline$F$ & 69.154 \\
$P$ & .000 \\
$R$ & .301 \\
$R$ Square & .090 \\
\hline
\end{tabular}

In addition, there is a significant positive effect between verbal tests with religious education achievements of Islamic school students $(\beta=.347 ; \mathrm{t}=7,053 ; \mathrm{r}=.186 ; \mathrm{p}=.000)$. It means that the higher the verbal test score, the higher the achievement of religious education. Similarly, the lower the verbal test scores the lower the achievement of religious education. Furthermore, this finding also reveals that there is a significant correlation between the reasoning test and the religious education achievements of Islamic school students $(\beta=.264 ; \mathrm{t}=.173 ; \mathrm{r}=.168 ; \mathrm{p}=.000)$. In other words, the higher the reasoning test score, the higher the achievement of religious education. Similarly, the lower the reasoning test score, the lower the achievement of religious education.

Table 3. Multiple regression analysis of personality traits on religious education achievement

\begin{tabular}{cc}
\hline Statistic & Value \\
\hline$F$ & 6.049 \\
$P$ & .000 \\
$R$ & .146 \\
$R$ Square & .018 \\
\hline
\end{tabular}

Table 3 shows that there is a simultaneous influence on the personality type (Big Five Personality) on the educational achievement of Islamic school students. When it is compared to the influence of the two predictor variables (cognitive and personality tests) on the achievement of religious education, cognitive tests have more influence than personality tests, $9 \%$, and $1.8 \%$.

Table 4. The influence of each personality traits on religious education achievement

\begin{tabular}{lcccc}
\hline Personality Dimensions & $B$ & $T$ & $R$ & $P$ \\
\hline Openness to experience & 1.623 & 3.016 & .081 & .003 \\
Conscientiousness & 1.409 & 2.329 & .062 & .020 \\
Extraversion & -.211 & -.356 & .010 & .722 \\
Agreeableness & -1.312 & -2.192 & .059 & .029 \\
Emotional stability & 1.147 & 1.944 & .052 & .052 \\
\hline
\end{tabular}

Table 4 shows that among the personality dimension, only the personality types of openness to experience and conscientiousness have a significant effect on the educational achievement of Islamic school students. While the agreeableness has a significant negative effect on the educational achievement of Islamic school students. Similarly, the personality types of extraversion and emotional stability have no significant effect on the religious education achievements of Islamic school students.

Table 5. Multiple regression analysis of cognitive test on Islamic studies achievement

\begin{tabular}{cc}
\hline Statistic & Value \\
\hline$F$ & 60.900 \\
$P$ & .000 \\
$R$ & .282 \\
$R$ Square & .080 \\
\hline
\end{tabular}

Table 5 shows that there is a significant partial effect between cognitive tests (verbal and reasoning) and the achievements of Islamic Studies subjects in Islamic school students ( $\mathrm{F}=$ 60,$900 ; \mathrm{P}=.000$ ). Both verbal and reasoning tests can be used as significant predictors of the achievements of Islamic Studies subjects in Islamic school students. 
There is a significant positive influence between verbal tests and the achievements of Islamic Studies subjects in Islamic school students $(\beta=.190 ; \mathrm{t}=6,561 ; \mathrm{r}=.173 ; \mathrm{p}=.000)$. It indicates that the higher the verbal test scores, the higher the performance of Islamic Studies subjects. Similarly, the lower the verbal test scores the lower the performance of Islamic Studies subjects. Furthermore, the finding shows that there is a significant effect between reasoning tests and Islamic Studies subject achievement in Islamic school students $(\beta=.147 ; \mathrm{t}=.6 .012 ; \mathrm{r}=.159$; $\mathrm{p}=.000$ ). In other words, the higher the reasoning test score, the higher the achievement of Islamic Studies subjects. Likewise, the lower the reasoning test score, the lower the performance of Islamic Studies subjects.

Table 6 shows that there is a simultaneous influence of personality type (Big Five Personality) on the students' achievement of Islamic Studies subjects in an Islamic school. When it is compared to the influence of the two predictor variables (cognitive and personality tests) on the achievement of Islamic Studies subjects, cognitive tests have a higher effect than personality types, $8 \%$, and $2 \%$.

Table 6. Multiple regression analysis of personality traits on Islamic studies achievement

\begin{tabular}{cc}
\hline Statistic & Value \\
\hline$F$ & 5.702 \\
$P$ & .000 \\
$R$ & .142 \\
$R$ Square & .020 \\
\hline
\end{tabular}

Table 7 shows that there is 3 personality dimensions, only conscientiousness, and emotional stability have a significant effect on the students' achievement of Islamic Studies subjects in an Islamic school. On the contrary, the agreeableness personality type has a significant negative effect on the achievement of Islamic Studies subjects in Islamic school students. Likewise, personality types of extraversion and openness to experience has no significant effect on the students' achievement of Islamic Studies subjects in an Islamic school.

Table 7. The influence of each personality traits on Islamic studies achievement

\begin{tabular}{lcccc}
\hline Personality Dimensions & $B$ & $T$ & $R$ & $P$ \\
\hline Openness to experience & .335 & 1.064 & .029 & .287 \\
Conscientiousness & 1.060 & 2.293 & .080 & .003 \\
Extraversion & .177 & .509 & .014 & .611 \\
Agreeableness & -.839 & -2.394 & -.064 & .017 \\
Emotional stability & .792 & 2.293 & .064 & .022 \\
\hline
\end{tabular}

Table 8 shows that there is a significant partial effect between cognitive tests (verbal and reasoning) and the students' achievement of Arabic subjects in Islamic school ( $\mathrm{F}=37,031 ; \mathrm{P}=$ $.000)$. Both verbal and reasoning tests can be used as a significant predictor of the students' achievement of Arabic subjects in an Islamic school.

Table 8. Multiple regression analysis of cognitive test on Arabic achievement

\begin{tabular}{cc}
\hline Statistic & Value \\
\hline$F$ & 37.031 \\
$P$ & .000 \\
$R$ & .225 \\
$R$ Square & .050 \\
\hline
\end{tabular}

There is a significant influence between verbal tests with students' the achievement of Arabic subjects in Islamic school $(\beta=.157 ; \mathrm{t}=5.212 ; \mathrm{r}=.138 ; \mathrm{p}=.000)$. It indicates that the higher the verbal test scores the higher the achievement of Arabic subjects. In other word, the lower the verbal test scores the lower the performance of Arabic subjects. In addition, the finding also shows that there is a significant effect between reasoning tests and the students' achievement of Arabic subjects in Islamic school $(\beta=.117 ; \mathrm{t}=.4888 ; \mathrm{r}=.122 ; \mathrm{p}=.000)$. It shows that the higher 
the reasoning test score, the higher the achievement of Arabic subjects. In the same way, the lower the reasoning test score the lower the achievement of Arabic subjects.

Table 9. Multiple regression analysis of personality traits on Arabic achievement

\begin{tabular}{cc}
\hline Statistic & Value \\
\hline$F$ & 4.551 \\
$P$ & .000 \\
$R$ & .127 \\
$R$ Square & .016 \\
\hline
\end{tabular}

Table 9 shows that there is a simultaneous influence on personality type (Big Five Personality) on the achievement of Arabic subjects in Islamic school students. When it is compared to the influence of the two predictor variables (cognitive and personality tests) on the achievement of Arabic subjects, the cognitive test was more influential than the personality type; $5 \%$ and $1.6 \%$.

Table 10. The influence of each personality traits on Arabic achievement

\begin{tabular}{lcccc}
\hline Personality Dimensions & $B$ & $T$ & $R$ & $P$ \\
\hline Openness to experience & 1.290 & 3.987 & .106 & .000 \\
Conscientiousness & .356 & .966 & .026 & .334 \\
Extraversion & -.386 & -1.083 & -.029 & .279 \\
Agreeableness & -.479 & -1.330 & -.036 & .184 \\
Emotional stability & .356 & 1.004 & .027 & .315 \\
\hline
\end{tabular}

Table 10 shows that among the personality dimension, only openness to experience has a significant positive effect on the students' achievement of Arabic subjects in an Islamic school. While the four personality types of extraversion, agreeableness, conscientiousness and emotional stability have no significant effect on the achievement of Arabic subjects in Islamic school students.

Table 11. Intercorrelation of cognitive and personality traits on academic achievement

\begin{tabular}{|c|c|c|c|c|c|c|c|c|c|}
\hline & VER & REA & EXT & AGR & $\mathrm{CON}$ & EMO & OPEN & Islamic & Arabic \\
\hline \multirow[t]{2}{*}{ VER } & 1 & $.350^{* *}$ & $.085^{* *}$ & -.002 & $.055^{*}$ & $.074^{* *}$ & $.130^{* *}$ & $.238^{* *}$ & $.190^{* *}$ \\
\hline & & .000 & .002 & .952 & .039 & .005 & .000 & .000 & .000 \\
\hline \multirow[t]{2}{*}{ REA } & & 1 & $.120^{* *}$ & $.053^{*}$ & $.059^{*}$ & $.087^{* *}$ & $.110^{* *}$ & $.228^{* *}$ & $.179^{* *}$ \\
\hline & & & .000 & .046 & .026 & .001 & .000 & .000 & .000 \\
\hline \multirow[t]{2}{*}{ EXT } & & & 1 & $.457^{* *}$ & $.330^{* *}$ & $.427^{* *}$ & $.371^{* *}$ & $.056^{*}$ & .013 \\
\hline & & & & .000 & .000 & .000 & .000 & .038 & .615 \\
\hline \multirow[t]{2}{*}{ AGR } & & & & 1 & $.478^{* *}$ & $.373^{* *}$ & $.325^{* *}$ & .013 & .006 \\
\hline & & & & & .000 & .000 & .000 & .618 & .813 \\
\hline \multirow[t]{2}{*}{ CON } & & & & & 1 & $.438^{* *}$ & $.371^{* *}$ & $.109^{* *}$ & $.058^{*}$ \\
\hline & & & & & & .000 & .000 & .000 & .032 \\
\hline \multirow[t]{2}{*}{ EMO } & & & & & & 1 & $.277^{* *}$ & $.102^{* *}$ & .048 \\
\hline & & & & & & & .000 & .000 & .076 \\
\hline \multirow[t]{2}{*}{ OPEN } & & & & & & & 1 & $.069^{*}$ & $.113^{* *}$ \\
\hline & & & & & & & & .010 & .000 \\
\hline \multirow[t]{2}{*}{ Islamic } & & & & & & & & 1 & $.426^{* *}$ \\
\hline & & & & & & & & & .000 \\
\hline Arabic & & & & & & & & & 1 \\
\hline \multicolumn{10}{|c|}{$\begin{array}{l}\mathrm{VER}=\text { Verbal; } \mathrm{REA}=\mathrm{Reasoning} \text { EXT = Extraversion; } \\
\text { Emotional Stability; OPEN = Openness to Experience } \\
* * .>.01 \\
* .>.05\end{array}$} \\
\hline
\end{tabular}


Table 11 shows that almost all cognitive variables and personality dimensions have a significant correlation with the achievement of religious education (Islamic Studies and Arabic). Only verbal tests with agreeableness personality; reasoning tests with agreeableness personality; and emotional stability with the achievement of Arabic subjects have no significant correlation.

\section{DISCUSSION and CONCLUSIONS}

This study shows that emotional tests and personality dimensions were significantly predict for students' achievement of religious major. This study was consistent with Lievens \& Coetsier (2002); Noftle \& Robins (2007); Rohde \& Thompson (2007); Van der Merwe \& De Beer (2006); Galleher, Rundquist, Barker, \& Chang (2012); Vitulić \& Prosen (2012); Finn, Kraft, West, Leonard, Bish, Martin, \& Gabrieli (2014); and Dević (2019) who explained that cognitive tests and personality dimension have a high predictive level for student academic achievement. In addition, cognitive tests (verbal and reasoning) have a significant correlation toward the students' achievement of religious major. It shows that the higher the cognitive test scores, the higher the students' achievement. Similarly, the lower the cognitive test scores, the lower the students' achievement.

The verbal tests show a significant correlation toward the achievement of religious subjects; Islamic Studies and Arabic subjects. Similarly, Alsager \& Milton (2016) revealed that there is a relationship between vocabulary knowledge and academic success. Likewise, Moskovsky, Alshahrani, Ratcheva, \& Paolini (2015) assumed that verbal test in aptitude tests are predictors of language achievement. In addition, Giofrè, Donolato, \& Mammarella, (2018) assumed that verbal tests are able to predict academic achievement. Similarly, Burton, Welsh, Kostin, VanEssen, \& Service (2009) and Anazia (2019) showed that verbal tests are strong predictors of academic achievement.

In addition, the reasoning test has a significant correlation toward the achievement of religious subjects; Islamic Studies and Arabic subjects. It indicates that the higher the reasoning test score, the higher the achievement of religious subjects. Similarly, the lower the reasoning test score, the lower the achievement of religious subjects. In the same way, Díaz-Morales \& Escribano (2013); Nnorom (2013); Pasnak, Kidd, Gadzichowski, Gallington, Schmerold, \& West (2015); Bhat (2016); Rani (2017); Gómez-Veiga, Vila Chaves, Duque, \& García Madruga (2018); Williamson \& Anderson (2019) revealed that students' reasoning abilities are strong predictors of students' academic achievement.

Similarly, the Big Five personality test simultaneously has a significant correlation with the achievement of religious subjects. It shows that the Big Five Personality test can be used as a predictor variable to predict student academic achievement. Thought, in partial, the finding of this study shows different effects among the five dimensions of the Big Five Personality. In the same way, Akomolafe (2013); McGeown, Putwain, Geijer Simpson, Boffey, Markham, \& Vince (2014); Gray, McGuinness, \& Owende (2014); Halim \& Chieng (2016); Angelkoska, Stankovska, \& Dimitrovski (2016); Varadwaj (2017); Novikova \& Vorobyeva (2017); Vedel \& Poropat (2017); Sorić, Penezić, \& Burić (2017); Vrdoljak, Lovaković, \& Kurtović (2018) stated that Big Five personality is a predictor of students' academic achievement.

In partial among the five dimensions of the Big Five Personality, only the personality type of openness to experience and conscientiousness have a significant positive effect on students' religious subjects' achievement. It indicates that the students who have the openness to experience and conscientiousness tend to have high religious subjects' achievements. The findings of this study are in line with Paunonen \& Ashton (2001); Geramian, Mashayekhi, \& Ninggal (2012) who assumed that openness to experience and conscientiousness is the strongest predictors of academic achievement. In the same way, Stewart, Bond, Deeds, Westrick, \& Wong (1999); Ehrler (2005); Treiber (2010); Nighute, S., \& Sadawarte, S. K. (2014); Gatzka \& Hell (2018); Mammadov, Cross, \& Ward (2018); Thomas \& Cassady (2019) revealed that openness to experience and conscientiousness is very important predictors in predicting academic achievement. 
Similarly, Woo, Saef, Parrigon, \& Lafayette, (2015) believed that the openness to experience is a very important personality possessed by an individual. Because a person who has the personality trait of openness to experience tends to have behavior, attitudes, and interests towards new things (novelty), creative and intelligent. A person with an openness to experience tend to like challenges, motivated to study hard, and pursue high achievements. In the same way, Smrtnik-Vitulić \& Zupančič (2011); Janošević \& Petrović (2019) assumed that the personality type of conscientiousness has the highest influence on academic achievement. Students who have a conscientiousness personality type tend to have a high awareness and responsibility for learning which influences students' achievement. According to Safdar \& Ullah (2013), that the type of personality conscientiousness that most strongly influences the Islamic Education subject. Similarly, Song, Gaspard, Nagengast, \& Trautwein (2020) stated that a person who has a conscientiousness personality tends to have a strong desire and effort for achieving high academic achievement. In addition, a person who has a conscientiousness personality tends to have a strong effort for academic achievement (Trautwein et al., 2009).

The findings of this study also indicate that agreeableness has a significantly negative effect on the educational achievement of Islamic school students. In other words, students who have an agreeableness personality tend to have low academic achievement. Similarly, Hakimi, Hejazi, \& Lavasani (2011); Rajapakshe (2017) revealed that agreeableness personality is negatively correlated with academic achievement. On the other hand, Chowdhury \& Amin (2006) assumed that agreeableness personality positively correlates with academic achievement. Furthermore, the personality types of extraversion and emotional stability showed no significant effect on the educational achievement of Islamic school students. In the same way, Smrtnik-Vitulić \& Zupančič (2011) revealed that students who have low extraversion personality types do not influence academic achievement. Similarly, Nighute, S., \& Sadawarte, S. K. (2014) showed that the personality type of extraversion was not a significant predictor for academic achievement.

After conducting the multiple-correlation test in this study, it can be seen that almost all variables have a significant relationship between cognitive variables and personality dimensions with the achievement of religious education (Islamic Studies and Arabic). On the contrary, verbal tests with agreeableness personality; reasoning tests with agreeableness personality; and emotional stability with the achievement of Arabic subjects have no significant relationship. This research supports previous research such as Halim, F. wati, \& Chieng, L. S. (2016). Based on these findings, even verbal and reasoning tests are also part and Big Five Personality needs to be taken into consideration as a predictor variable to predict student academic achievement.

Based on the explanation above, it can be concluded that cognitive tests and personality types are simultaneously significant predictors of the achievement of the religious subject. Furthermore, in partial, verbal tests and reasoning are also significant predictors of the achievements of religious education in both Islamic Studies and Arabic. Similarly, from the five dimensions of the Big Five Personality, the strongest personality types, openness to experience and conscientiousness are predictors of the achievements of religious subjects. While agreeableness negatively influences the achievement of religious subjects. Thought, extraversion, and emotional stability showed no significant effect on the achievement of religious subjects. Further research can reach the entire national admission system of state Islamic senior high schools in Indonesia namely Islamic senior high schools Insan Cendekia, which is also a state boarding school in Indonesia.

\section{REFERENCES}

Akomolafe, M. J. (2013). Personality characteristics as predictors of academic performance of secondary school students. Mediterranean Journal of Social Sciences, 4(2), 657.

Alsager, R., \& Milton, J. (2016). Investigating the Relationship between Vocabulary Knowledge and Academic Success of Arabic Undergraduate Learners in Swansea University. Language in Focus, 2(2), 88-124.

Anazia, I. U. (2019). Quantitative and Verbal Aptitudes as Predictors of Senior Secondary School Students' Performance in Economics. IAFOR Journal of Education, 7(1), 7-18. 
Angelkoska, S., Stankovska, G., \& Dimitrovski, D. (2016). The Personal Characteristics Predictors of Academic Success. Bulgarian Comparative Education Society.

Arifah, M., Murwatiningsih, M., \& Harlanu, M. (2019). Boarding School Management on Students' Character Building in An-Nawawiyyah Islamic Junior High School Rembang. Educational Management, 8(2), 209-213.

Azani, M. Z. (2019). Literasi digital keagamaan aktivis organisasi religious digital literacy of religious organization activism. Tsaqofah, 05(01), 1-27.

Bhat, M. A. (2016). The predictive power of reasoning ability on academic achievement. International Journal of Learning, Teaching and Educational Research, 15(1).

Burton, N. W., Welsh, C., Kostin, I., \& van Essen, T. (2009). Toward a definition of verbal reasoning in higher education. ETS Research Report Series, 2009(2), i-41.

Chowdhury, M. S., \& Amin, M. N. (2006). Personality And Students'academic Achievement: Interactive Effects Of Conscientiousness And Agreeableness On Students'performance In Principles Of Economics. Social Behavior and Personality: An International Journal, 34(4), 381-388.

Demasi, A. (2013). Psychometric testing in the selection process. Keeping Good Companies, 65(1), 50.

Dević, I. (2019). Student School Achievement: Testing a Model of Academic Competence. Društvena Istraživanja: Časopis Za Opća Društvena Pitanja, 28(3), 523-542.

Díaz-Morales, J. F., \& Escribano, C. (2013). Predicting school achievement: The role of inductive reasoning, sleep length and morningness-eveningness. Personality and Individual Differences, 55(2), 106-111.

Ehrler, D. J. (2005). An investigation into the relation between the Five-Factor Model of personality and academic achievement in children. Georgia State University.

Finn, A. S., Kraft, M. A., West, M. R., Leonard, J. A., Bish, C. E., Martin, R. E., Sheridan, M. A., Gabrieli, C. F. O., \& Gabrieli, J. D. E. (2014). Cognitive skills, student achievement tests, and schools. Psychological Science, 25(3), 736-744.

Galleher, C., Rundquist, P. J., Barker, D. B., \& Chang, W.-P. (2012). Determining cognitive and non-cognitive predictors of success on the National Physical Therapy Examination. Internet Journal of Allied Health Sciences and Practice, $10(4), 7$.

Gatzka, T., \& Hell, B. (2018). Openness and postsecondary academic performance: A meta-analysis of facetaspect, and dimension-level correlations. Journal of Educational Psychology, 110(3), 355.

Geramian, S. M., Mashayekhi, S., \& Ninggal, M. T. B. H. (2012). The relationship between personality traits of international students and academic achievement. Procedia-Social and Behavioral Sciences, 46, 4374-4379.

Ghazi, S. R., Shahzada, G., \& Ullah, S. (2013). Relationship between students' personality traits and their academic achievement in Khyber Pakhtunkhwa, Pakistan. Journal of Educational and Social Research, $3(2), 437$.

Giofre, D., Donolato, E., \& Mammarella, I. C. (2018). Verbal and visuospatial WM \& academic achievement. Trends in Neuroscience and Education.

Gómez-Veiga, I., Vila Chaves, J. O., Duque, G., \& García Madruga, J. A. (2018). A New Look to a Classic Issue: Reasoning and Academic Achievement at Secondary School. Frontiers in Psychology, 9, 400.

Gray, G., McGuinness, C., \& Owende, P. (2014). Non-cognitive factors of learning as predictors of academic performance in tertiary education.

Hakimi, S., Hejazi, E., \& Lavasani, M. G. (2011). The relationships between personality traits and students' academic achievement. Procedia-Social and Behavioral Sciences, 29, 836-845.

Halim, F. wati, \& Chieng, L. S. (2016). Hubungan Antara Determinasi Kendiri, Personaliti Big Five Dengan Motivasi Pencapaian Dan Pencapaian Akademik (The Relationship Of Self Determination And Big Five Personality To Achievement Motivation And Academic Achievement). Jurnal Psikologi Malaysia, $30(2)$.

Hastuti, T., \& Jumidah, J. (2017). Pengaruh Boarding School Terhadap Disiplin, Motivasi, Dan Minat Belajar Siswa Pada Mata Pelajaran Kewirausahaan Kelas X Smkn Pertanian Terpadu Provinsi Riau. Jurnal Perspektif Pendidikan Dan Keguruan, 7(14), 60-67.

Hewgley, L. (2013). Cognitive, personality, and biodata predictors of police academy attrition. Middle Tennessee State University.

Janošević, M., \& Petrović, B. (2019). Effects of personality traits and social status on academic achievement: Gender differences. Psychology in the Schools, 56(4), 497-509.

Khafidin, Z. (2014). Analisis Validitas dan Reliabilitas tes Mata Pelajaran Pendidikan Agama Islam tingkat SMA. Edukasia: Jurnal Penelitian Pendidikan Islam, 9(2).

Khine, M. S. (2016). Non-cognitive skills and factors in educational success and academic achievement. In Non-cognitive Skills and Factors in Educational Attainment (pp. 1-9). Brill Sense.

Krisna, I. I. (2019). Prediksi Tes Bakat Skolastik Terhadap Prestasi Belajar Siswa Sekolah Menengah Atas. 
Indonesian Journal of Educational Assesment, 1(1), 35.

Lee, S.-J., Choi, W., Kim, S. Y., \& Choi, J.-W. (2009). Correlation of academic achievements with cognitive admission variables and demographics at Chungbuk National University Graduate Medical School. Korean Journal of Medical Education, 21(1), 59-66.

Lievens, F., \& Coetsier, P. (2002). Situational tests in student selection: An examination of predictive validity, adverse impact, and construct validity. International Journal of Selection and Assessment, 10(4), 245-257.

Lipnevich, A. A., \& Roberts, R. D. (2012). Noncognitive skills in education: Emerging research and applications in a variety of international contexts. Learning and Individual Differences, 22(2), 173177.

MacKenzie, R. K., Dowell, J., Ayansina, D., \& Cleland, J. A. (2017). Do personality traits assessed on medical school admission predict exit performance? A UK-wide longitudinal cohort study. Advances in Health Sciences Education, 22(2), 365-385.

Mammadov, S., Cross, T. L., \& Ward, T. J. (2018). The Big Five personality predictors of academic achievement in gifted students: Mediation by self-regulatory efficacy and academic motivation. High Ability Studies, 29(2), 111-133.

McGeown, S. P., Putwain, D., Simpson, E. G., Boffey, E., Markham, J., \& Vince, A. (2014). Predictors of adolescents' academic motivation: Personality, self-efficacy and adolescents' characteristics. Learning and Individual Differences, 32, 278-286.

Moskovsky, C., Alshahrani, A., Ratcheva, S., \& Paolini, S. (2015). Aptitude as a predictor of second language achievement: an investigation in the Saudi Arabian context. Arab World English Journal (AWEJ), 6(1).

Muhid, A. (2012). Analisis Statistik. Sidoarjo: Zifatama.

Muñoz, N. N., Barraza, R. L., Pérez, C. V, \& Ortiz, L. M. (2015). Rethinking the selection of medical students, considering non-cognitive skills. Revista Medica de Chile, 143(10), 1337-1342.

Muslim, A. (2017). Pembinaan Kesiswaan Berbasis Sastra Religi Di Madrasah Aliyah Negeri 1 Palu. Pusaka, $5(1), 1-22$.

Nighute, S., \& Sadawarte, S. K. (2014). Relationship between big five personality traits and academic performance in medical students. J of Evol Med Dent Sci, 3(17).

Nnorom, N. R. (2013). The Effect of Reasoning Skills on Students Achievement in Biology in Anambra State. International Journal of Scientific \& Engineering Research, 4(12), 2102-2104.

Noftle, E. E., \& Robins, R. W. (2007). Personality predictors of academic outcomes: big five correlates of GPA and SAT scores. Journal of Personality and Social Psychology, 93(1), 116.

Novikova, I. A., \& Vorobyeva, A. A. (2017). Big Five Factors and academic achievement in Russian students. Psychology in Russia, 10(4), 95.

Nur, M. (2019). Literasi Digital Keagamaan Aktivis Organisasi Keagamaan Di Madrasah Aliyah Negeri (Man) Di Kota Bandung. Jurnal SMART (Studi Masyarakat, Religi, Dan Tradisi), 5(1), 1-14.

Pasnak, R., Kidd, J. K., Gadzichowski, K. M., Gallington, D. A., Schmerold, K. L., \& West, H. (2015). Abstracting sequences: Reasoning that is a key to academic achievement. Journal of Genetic Psychology, 176(3), 171-193. https://doi.org/10.1080/00221325.2015.1024198

Paunonen, S. V, \& Ashton, M. C. (2001). Big Five predictors of academic achievement. Journal of Research in Personality, 35(1), 78-90.

Permatasari, T. O. (2016). Faktor kognitif dan non-kognitif pada seleksi mahasiswa baru sebagai prediktor terhadap prestasi akademik. Jurnal Penelitian Dan Evaluasi Pendidikan, 20(1), 80-89.

Rajapakshe, W. (2017). A Study on the Big Five Personality Dimensions' Effect on University Students' Academic Performance. IOSR Journal of Business and Management (IOSR-JBM)., 19(12), 69-75.

Ranasinghe, P., Ellawela, A., \& Gunatilake, S. B. (2012). Non-cognitive characteristics predicting academic success among medical students in Sri Lanka. BMC Medical Education, 12(1), 66.

Rani, K. V. (2017). Reasoning Ability and Academic Achievement among Secondary School Students in Trivandrum. Journal on School Educational Technology, 13(2), 20-30.

Rohde, T. E., \& Thompson, L. A. (2007). Predicting academic achievement with cognitive ability. Intelligence, 35(1), 83-92.

Rohmah, M. R., \& Arifin, Z. (2017). Eksistensi dan Pengembangan Kurikulum Madrasah Aliyah Program Keagamaan (MAPK) MAN 1 Surakarta. Jurnal Pendidikan Madrasah, 2(2), 369-384.

Rosanti, F. D., Budiwibowo, S., \& Astuti, E. (2018). Analisis Mana Jemen Risiko Dalam Pengembangan Mutu Pendidikan Di Man 4 Madiun. FIPA: Forum Ilmiah Pendidikan Akuntansi, 6(2).

Rukmana, D. (2014). Quota Sampling BT - Encyclopedia of Quality of Life and Well-Being Research (A. C. Michalos (ed.); pp. 5382-5384). Springer Netherlands. https://doi.org/10.1007/978-94-007-0753$5 \_2393$

Salman, I. (2016). Evaluasi program ekstrakurikuler seni keagamaan di MAN 8 Jakarta. Penamas, 29(2), 
279-296.

Smrtnik-Vitulić, H., \& Zupančič, M. (2011). Personality traits as a predictor of academic achievement in adolescents. Educational Studies, 37(2), 127-140.

Song, J., Gaspard, H., Nagengast, B., \& Trautwein, U. (2020). The Conscientiousness Interest Compensation (CONIC) model: Generalizability across domains, outcomes, and predictors. Journal of Educational Psychology, 112(2), 271.

Sorić, I., Penezić, Z., \& Burić, I. (2017). The Big Five personality traits, goal orientations, and academic achievement. Learning and Individual Differences, 54, 126-134.

Stewart, S. M., Bond, M. H., Deeds, O., Westrick, J., \& Wong, C. M. (1999). Predictors of high school achievement in a Hong Kong international school. International Journal of Psychology, 34(3), 163-174.

Sulphey, M. M., Al-Kahtani, N. S., \& Syed, A. M. (2018). Relationship between admission grades and academic achievement.

Surur, A. M. (2018). Upaya Menanamkan Nilai Religius Siswa Di MAN Kediri 1 Kota Kediri Dengan Ekstrakurikuler Keagaman Tahfidz Al-Qur'an. Jurnal Pendidikan Agama Islam, 15(1), 42-51.

Susiyani, A. S. (2017). Manajemen Boarding School dan Relevansinya dengan Tujuan Pendidikan Islam di Muhammadiyah Boarding School (MBS) Yogyakarta. Jurnal Pendidikan Madrasah, 2(2), 327-347.

Suwendi, S. (2017). Restrukturisasi MAK: Studi Kebijakan Penyelenggaraan Program Tafaqquh fid-Din Era UU Sisdiknas No 20 Tahun 2003. Edukasi, 4(4), 294534.

Thomas, C. L., \& Cassady, J. C. (2019). The influence of personality factors, value appraisals, and control appraisals on cognitive test anxiety. Psychology in the Schools, 56(10), 1568-1582.

Trautwein, U., Lüdtke, O., Roberts, B. W., Schnyder, I., \& Niggli, A. (2009). Different forces, same consequence: Conscientiousness and competence beliefs are independent predictors of academic effort and achievement. Journal of Personality and Social Psychology, 97(6), 1115.

Treiber, J. (2010). Conscientiousness, Openness, and Gender as Academic Predictive Variables InHigh School Seniors. Walden University.

Urlings-Strop, L. C., Stegers-Jager, K. M., Stijnen, T., \& Themmen, A. P. N. (2013). Academic and non-academic selection criteria in predicting medical school performance. Medical Teacher, 35(6), 497-502.

Van der Merwe, D., \& De Beer, M. (2006). Challenges of student selection: Predicting academic performance. South African Journal of Higher Education, 20(4), 547-562.

Varadwaj, K. (2017). Mediation of academic self-concept between big five personality and academic performance. IOSR Journal of Humanities and Social Science (IOSR-JHSS, 22(8), 29-34. https://doi.org/. https://doi.org/10.9790/0837-2212082934

Vedel, A., \& Poropat, A. E. (2017). Personality and academic performance. Encyclopedia of Personality and Individual Differences, 1-9.

Vitulić, H. S., \& Prosen, S. (2012). Personality And Cognitive Abilities As Predictors Of University Students'academic Achievement. Društvena Istraživanja, 21(3), 715-732.

Vrdoljak, G., Kurtović, A., \& Lovaković, I. (2018). Personality traits, goal orientations and school achievement. 13th Alps Adria Psychology Conference.

Warsah, I., \& Nuzuar, N. (2018). Analisis Inovasi Administrasi Guru dalam Meningkatkan Mutu Pembelajaran (Studi Man Rejang Lebong). Edukasi, 16(3), 294572.

Williamson III, K. C., \& Anderson, A. J. (2019). Reasoning ability as a predictor of success in a construction surveying course. International Journal of Construction Education and Research, 15(1), 42-61.

Woo, S. E., Saef, R., Parrigon, S., \& Lafayette, W. (2015). Openness to Experience. In International Encyclopedia of Social \& Behavioral Sciences (Second Edition, Vol. 17). Elsevier. https://doi.org/10.1016/B978-0-08-097086-8.25072-1

Zulfa, N. C., \& Pardjono, P. (2013). Manajemen Kurikulum Madrasah Aliyah Program Keagamaan MAN 1 Surakarta. Jurnal Akuntabilitas Manajemen Pendidikan, 1(2), 219-234. 